\title{
Representações do Brasil Moderno para ler, ver e ouvir no circuito dos Museus Commerciais Europeus, 1906 a 1908
}

\author{
Maria Eliza Linhares Borges* \\ Quando o acontecimento tiver \\ acabado, a fotografia ainda \\ existirá, o que confere ao \\ acontecimento uma espécie de \\ imortalidade (e importância) que \\ de outro modo nunca teria. \\ Susan Sontag
}

\section{Resumo:}

O artigo versa sobre o papel da cultura visual na construção da identidade nacional brasileira nos primeiros anos da era republicana. Analisa as práticas publicitárias das elites brasileiras destinadas a substituir a imagem do Brasil pitoresco - em circulação dentro e fora do país desde o século XIX - por outra mais afinada com os signos de uma sociedade moderna e cosmopolita. É dada ênfase à produção e circulação de bens simbólicos editados pelo Museu Commercial do Rio de Janeiro e o Museu Commercial Brasileiro em Paris, em parceria com o Serviço de Propaganda e Expansão Econômica do Brasil no Estrangeiro, no período que antecedeu à Exposição Nacional de 1908, realizada para celebrar o Primeiro Centenário da chegada da Corte Portuguesa no Brasil.

Palavras-chave: Cultura Visual, Circulação de Bens Simbólicos, Identidade Nacional

A proliferação de tecnologias visuais, principalmente a partir da revolução digital, é uma das tantas evidências do pool de mudanças que permeia as relações sociais no tempo presente. Todos reconhecemos o quanto a cultura dos weblogs, realityshows, sites de buscas, câmeras digitais, instaladas até mesmo nos aparelhos celulares, alterou nossas percepções da realidade e as formas de representação que a nomeiam, organizam, simbolizam, enfim, que lhe atribuem sentido. Hoje, as imagens fixas ou móveis adentram nosso cotidiano tão logo iniciamos as atividades diárias. Inflacionados de imagens, muitas vezes nem sequer as percebemos. Passando de uma a outra, poucas são as que retemos na memória.

Terão as imagens perdido seu potencial cognitivo? Em outras palavras: terão elas deixado de nos encantar, de nos convidar à fantasia ou mesmo de nos instigar a problematizar suas relações com as culturas que as produzem e utilizam? 
A julgar pela profusão de revistas, livros, sites, eventos, disciplinas e debates dedicados a refletir sobre temas relativos ao campo da cultura visual, vemos que a inflação de imagens tem outras faces além da aparente cegueira. Tateando aqui e ali, com mais ou menos cautela, especialistas de diferentes áreas do conhecimento têm ensaiado e proposto chaves analíticas destinadas a explicar os modos de acreditar, ver e fazer, entender e significar, inscritos nos circuitos de produção, difusão e consumo de imagens. Ainda que o debate teórico-metodológico sobre a temática da cultura visual escape aos objetivos deste artigo ${ }^{1}$, não podemos desconhecer: as indagações sobre a visualidade no tempo presente não apenas problematizam as linhas de força da "videosfera", como também permitem avaliar seus elos e rupturas com a "grafosfera" e a "logosfera"2. Para aqueles que, como nós, têm interesse no estudo das formas simbólicas próprias da modernidade industrial, tais nexos são cruciais. Afinal, a fotografia - "último imprevisto da grafosfera"3 - mudou nossas relações com o mundo. Ao inserir-nos na era da reprodutibilidade das imagens ${ }^{4}$, ela fez do globo uma imensa aldeia bidimensional.

Embora a litografia tenha iniciado o processo de reprodução de imagens em escala de mercado ${ }^{5}$, foi com a fotografia que ele realmente deslanchou. Sua natureza indicial e reprodutível confundiu real e representação; encurtou as distâncias geográficas; rompeu com as fronteiras entre o público e o privado. Mais que isso: mudou os paradigmas que até então tinham orientado os modos de observar, crer e significar as relações sociais. Em pouco tempo essa imagem híbrida, invenção de muitas mãos e nacionalidades, tornou-se presença obrigatória nos diferentes eventos destinados a globalizar os artefatos e os hábitos da era industrial. Nos stands das Exposições Universais, ela funcionou como veículo de propaganda das inovações tecnológicas e das criações artísticas, além de ser, ela mesma, um objeto sociocultural ${ }^{6}$. Nos museus de ciência, a exemplo do Museu de História Natural de Paris, as coleções fotográficas alimentaram o sonho de racionalizar o estudo das raças ${ }^{7}$. Nas publicações das Sociedades Geográficas, as lentes fotográficas instituíram identidades sociais estereotipadas enquanto ilustravam os relatórios de viagens que classificavam e ordenavam, com critérios estrangeiros, os hábitos das sociedades então nomeadas de exóticas. Nas revistas ilustradas, editadas em praticamente todas as grandes cidades do mundo ocidental, a disputa por leitores fez da caricatura, reproduzida via litografia, um meio de crítica social, enquanto coube à fotografia a difusão dos valores da nova ordem social. Em meio a esse processo de fabricação e guerra de imaginários e identidades 
sociais, na vida privada, a cumplicidade entre fotógrafos e fotografados criava memórias consentidas de famílias. Adentrando todos os espaços sociais, as câmeras fotográficas contaminaram as demais linguagens visuais; mesclaram centro e periferia, fragilizaram as divisões entre o dentro e o fora.

A história que se segue tem as marcas das ambigüidades desse processo. Mais que evidências para o estudo de um período histórico específico, os dados de que dispomos conformam um campo de reflexão em si mesmo, isto é, impõem-nos trajetos, direções e ritmos próprios. Com eles, e a partir deles, veremos como os artefatos visuais participaram da construção de um dos maiores sonhos das elites republicanas brasileiras no alvorecer do século XX: a substituição da representação do Brasil pitoresco - criada e difundida ao longo do século XIX, dentro e fora do país - por outra mais afinada com os códigos socioculturais definidores da modernidade industrial.

\section{A República e o esforço de desmonte do Brasil pitoresco}

No tempo em que não aderir aos paradigmas mercadológicos, urbanísticos e comportamentais da modernidade industrial equivalia a pertencer à periferia do mundo civilizado e industrial ${ }^{8}$, os governos e as elites das ex-colônias iberoamericanas adotaram e implementaram versões nacionais das práticas modernizantes. Para tanto, instituíram políticas para expandir os meios de comunicação, investiram em reformas urbanas e sanitárias, abriram seus portos à importação de mercadorias, incentivaram a entrada de imigrantes estrangeiros, apoiaram projetos de industrialização e, sobretudo, lançaram mão das novas linguagens visuais para com elas se apresentarem nos espaços de difusão das inovações tecnológicas e dos hábitos identificados com o tempo da modernidade.

No Brasil, em particular, tal esforço data de fins do período imperial. Lembranos Turazzi que,

\footnotetext{
logo após os primeiros ensaios com a câmara, fotógrafos em atividade no Rio de Janeiro se associaram aos projetos modernizadores dos engenheiros que, à frente da administração municipal, de comissões, diretorias e ministérios do Império, e posteriormente da República, comandaram as transformações urbanísticas na capital do país?'.
}

Se é certo que a circulação de litografias e fotografias produzidas ao longo do Império rompeu com o imaginário fabuloso presente nas pranchas e ilustrações cartográficas que, entre os séculos XVI e XVIII, dividiam o Brasil entre canibalismo e 
paraíso terrestre, também é fato que as imagens dos viajantes oitocentistas criaram um país diverso: deram vida ao Brasil pitoresco ${ }^{10}$. Filiado, de um lado, à herança de A. Eckhout e Franz Post e, de outro, às preocupações científicas de A. Humboldt e realistas dos pintores de história, o Brasil pitoresco tinha elementos incompatíveis com o ideal de um país moderno e cosmopolita, alimentado por uma fração das elites nacionais desde fins do Império. Ao invés de ruas e portos cheios de negros e negras de ganho; o Brasil do tempo do progresso seria feito com paisagens "fidedignas" de uma natureza disciplinada pela mão engenhosa, higiênica e estetizante dos profissionais da vida urbana e ainda celebraria o glamour e o cosmopolitismo da burguesia e dos estratos médios citadinos. Enquanto os becos e as esquinas das vilas e cidades coloniais dariam lugar a largas e longas avenidas, arborizadas e iluminadas a gás ou eletricidade, ladeadas por bares, restaurantes, casas comerciais e livrarias; nas estradas, os carros de bois seriam substituídos por pontes, túneis e ferrovias, responsáveis pela ligação entre sertão e litoral, isto é, pela expansão do progresso ao longo do território nacional.

Proclamada a República e eliminados os chamados obstáculos internos à consolidação do novo regime - como ocorreu com a guerra contra os rebelados de Canudos -, as elites republicanas empenharam-se de forma sistemática na substituição da imagem do Brasil pitoresco por outra capaz de inserir o país no circuito das nações industrializadas e civilizadas.

A estabilidade necessária para tal empreendimento veio com o pacto oligárquico assentado durante o governo de Campos Sales (1898-1902) e continuado nas décadas seguintes. Pouco a pouco, os setores médios urbanos eram seduzidos a participar do circuito de consumo de bens materiais e simbólicos que definiam as fronteiras da belleépoque. Apesar da varíola que grassava na Capital Federal, os comerciantes anunciavam as últimas novidades chegadas da Europa. Nas páginas dos jornais, e sobretudo das revistas ilustradas, os fotógrafos locais ganhavam mais e mais espaço. Seus flagrantes do Rio smart veiculavam fotografias dos automóveis, bondes elétricos, teatros, cafés e maisons que exprimiam o anseio da modernidade carioca ${ }^{11}$. Entre 1903 e 1907 foram produzidas inúmeras fotografias das reformas da Avenida Central no Rio de Janeiro. Fotógrafos como Augusto Malta e Marc Ferrez destacaram-se entre os que monumentalizaram os detalhes das áreas remodeladas da Capital Federal. Poucos foram os que se interessaram pelas imagens das margens da nação moderna, instaladas a poucos metros dos espaços reformados. Cartões-postais da nação, a Avenida Central, a Avenida Beira Mar (Flamengo) e as praças de Botafogo agregavam valor novo à 
paisagem carioca. Vitrines do progresso, esses fragmentos do Rio de Janeiro eram apresentados como paraíso do capital e dos imigrantes estrangeiros.

Enquanto isso, as práticas modernizantes das elites republicanas mesclavam a memória da experiência escravista com a tradição positivista. Crédulos na eficácia da ação pedagógica de suas elites, os governantes mantinham a tradição de definir, de cima para baixo, como e em que condições os diferentes segmentos da sociedade civil figurariam no projeto modernizador. Os protestos populares, a exemplo da revolta da vacina (1904), e o controle das ações político-ideológicas que iam modelando a cultura operária nas áreas urbanas eram administrados com o pragmatismo que caracteriza as práticas políticas autoritárias ${ }^{12}$.

Em 1906, preocupado com as repercussões internacionais do aumento das fugas dos imigrantes das propriedades rurais, sobretudo no estado de São Paulo, o baiano Miguel Calmon du Pin e Almeida, ministro da Indústria, Viação e Obras Públicas, encomendou um relatório sobre tal situação. Após percorrer as regiões onde o descontentamento dos trabalhadores estrangeiros era mais patente, o funcionário do referido ministério redigiu seu diagnóstico. O "êxodo de imigrantes que assumia proporções assustadoras" e que "constituía sério motivo de desprestígio para nós aos olhos do estrangeiro" 13 poderia ser solucionado com medidas práticas. Dentre elas, destacavam-se a reorganização do desembarque, da recepção e hospedagem dos imigrantes, principalmente na hospedaria da Ilha das Flores, a designação de funcionários da União para conhecer as necessidades locais de emprego nos estados do Rio de Janeiro, São Paulo, Minas Gerais, Paraná e Santa Catarina e a "creação de um serviço de propaganda systemática e de informações do nosso país no estrangeiro, ... por quantos poderam observar a ignorancia no exterior dos assumptos que mais de perto nos tocam" $" 14$.

Nada foi dito sobre a permanência das relações de mando, essencialmente patriarcais, que conduziam o sistema de trabalho no campo.

Presente não apenas nas fazendas de café, mas também na construção de ferrovias, nas reformas dos portos brasileiros e nos projetos de remodelação urbana de diferentes capitais do país, o trabalhador estrangeiro era também um mediador da visibilidade do Brasil no exterior. A rede de sociabilidade que o vinculava a seus países de origem transcendia a esfera privada. Além dos parentes e amigos residentes na Europa ou instalados em outros territórios do globo, ela incluía as agências estrangeiras de imigração. Ainda que, por razões várias, uma parcela considerável dos imigrantes 
acabasse mascarando os problemas vivenciados no país, muitos eram os que desmistificavam o imaginário do Brasil "paraíso terrestre" dos imigrantes e acabavam acarretando "frequentes questões e difficuldades internacionaes" $" 15$ para a República.

Em meio a esse contexto, as elites republicanas tiveram seu kairós: o ano de 1908, data do primeiro centenário da chegada da Corte Portuguesa ao Brasil. Era preciso explorar essa oportunidade. O ministro Miguel Calmon du Pin e Almeida reuniu uma comissão de notáveis e propôs a realização de uma Exposição Nacional, nos moldes das Exposições Universais. Se bem montada, ela haveria de dissipar as sombras que impediam a visibilidade do Brasil moderno, cosmopolita, hospitaleiro e economicamente promissor. A celebração do primeiro centenário da chegada da Corte Portuguesa ao Brasil comemoraria também o primeiro centenário do Jardim Botânico e da Imprensa no Brasil. Em 30 de dezembro de 1906 foi publicada a Lei n. 1.617, cujo artigo n. 35 aprovava "as bases segundo as quaes havia de organizar-se uma Exposição Nacional em 1908, que se deveria abrir proximamente á chegada a esta capital [Rio de Janeiro] dos soberanos portugueses"16.

Além de monumentalizar o evento com a presença de S. M. El-Rey D. Carlos I no Brasil, esperava-se que o "certamem" fizesse um "balanço geral da riqueza do país [de modo a produzir] uma summa de nossa evolução durante um século"17. A produção visual prevista para a organização da Exposição Nacional de 1908 mostraria que o Brasil pitoresco era coisa do passado.

No calor das notícias que logo contagiaram lideranças dos diferentes segmentos das classes conservadoras, alguns membros da Academia de Commercio do Rio de Janeiro propuseram a criação de um Museu Commercial. Mais que a Exposição Nacional de 1908, é a história da ação conjunta do Museu Commercial do Rio de Janeiro e do Serviço de Propaganda e Expansão Econômica do Brasil no Estrangeiro criado em 3 de outubro de 1907, pelo Decreto-lei n. 6.688, e instalado em Paris no Boulevard d'Italiens ${ }^{18}$ - que nos interessa nesse momento. De fôlego aparentemente curto, suas evidências históricas nos remetem à Exposição Universal de Paris de 1867; fazem-nos transitar pelos Museus Comerciais europeus, entre fins do século XIX e início dos anos novecentos; trazem-nos de volta ao Brasil da Exposição Nacional de 1908, para, novamente, nos levarem à Europa dos anos que antecedem à Primeira Grande Guerra. Ao longo deste périplo, deparamo-nos com mapas, quadros estatísticos, coleções de amostras dos produtos brasileiros, litografias e fotografias de vistas urbanas do Rio de Janeiro, posterior à reforma Pereira Passos, e de outras capitais brasileiras. 
Objetos de propaganda no exterior, esses artefatos da cultura visual nutriram um imenso pacote para se ver, acreditar e difundir o Brasil moderno no mercado europeu.

\section{A parceria da modernidade republicana: o Museu Commercial do Rio de Janeiro e o Serviço de Propaganda e Expansão Econômica do Brasil no Estrangeiro}

Com uma dotação orçamentária modesta para os parâmetros da época, 25000\$00, o Museu Commercial do Rio de Janeiro foi instalado provisoriamente em uma sala contígua à Academia de Commercio. Concluída a reforma da Avenida Central, providenciou-se sua transferência para um de seus palacetes, "onde foram solenemmente reinaugurados os seus trabalhos, em 9 de março de 1907"19.

Entre os anos de 1907 e 1908, os dirigentes do Museu deram as providências para a organização das coleções in natura dos produtos brasileiros. Uma vez instalado na Avenida Central, a vitrine do Brasil em processo de modernização, o Museu Commercial do Rio de Janeiro pode se adequar ao modelo dos museus comerciais europeus. Além do espaço reservado à exposição dos produtos nacionais, ele dispunha de um Gabinete de Informações, uma Biblioteca e uma Sala para Conferências. Para a difusão de suas atividades, seus funcionários encarregavam-se dos contatos com os consulados estrangeiros instalados no Brasil, com as entidades das classes conservadoras do país e com os principais museus comerciais do exterior. Pelo menos uma vez por mês, a Academia de Commercio do Rio de Janeiro convidava palestrantes, brasileiros e estrangeiros, para discorrerem sobre temas relacionados com a produção e seu comércio dentro e fora do país. Além de informativos, esses eventos funcionavam como rituais de reafirmação e celebração da nova identidade nacional.

Mas, afinal, a que linhagem de museus pertencia o Museu Commercial do Rio de Janeiro? Como se verá a seguir, ele integrava a categoria dos Musées Commerciaux, concebidos em Paris logo após a Exposição Universal de Paris de 1867. Seus indícios abrem-nos a possibilidade, dentre outras, para compreendermos como as elites republicanas brasileiras participaram de uma rede internacional de comércio e propaganda tão crucial para a promoção da nova representação nacional no contexto mundial.

Dois anos após a realização da referida exposição, o senador e membro de sua Comissão Imperial, M. F. Le Play, concluíra um longo documento destinado a avaliar seus prós e contras. Em meio às análises, o colaborador de Napoleão III dizia que, 
apesar do sucesso de público, a era das Exposições Universais não duraria muito. Era, pois, chegada a hora de propor uma nova modalidade de exposição capaz de fazer o duplo trabalho de expor e divulgar as inovações tecnológicas, as criações artísticas e os estudos etnográficos e ainda fomentar o comércio nacional e internacional. Dentre os argumentos que fundamentavam sua tese, Le Play chamava a atenção para a natureza temporária das Exposições Universais, fato que as tornava cada vez mais onerosas, já que os prédios construídos tendiam a ficar ociosos tão logo seus stands eram desmontados. Em vista disso, o senador do II Império propunha a criação de duas novas modalidades de exposição: os Musées Généraux e os Musées Commerciaux ${ }^{20}$. A diferença entre eles era quase tão-somente de escala e localização. O primeiro tipo, dizia o curador: se adequaria mais às áreas rurais ou suburbanas, localizadas próximas dos grandes centros, e teria o papel de agregar os produtores em torno das necessidades regionais. A funcionalidade do segundo seria tanto maior quanto mais moderna e cosmopolita fosse a cidade onde ele estivesse instalado ${ }^{21}$.

Como todo e qualquer museu, eles também teriam uma função pedagógica: suas coleções fariam com que os visitantes se inteirassem sobre a produção, o trabalho e os hábitos de consumo das diferentes regiões nacionais. Diferentemente de outros museus, eles teriam uma especificidade: estariam voltados para "a primeira grande necessidade dos produtores" de qualquer país: a publicidade. Como espaços permanentes de exposição, seu cotidiano seria estruturado a partir da combinação entre exposições permanentes e temporárias, todas destinadas à promoção de debates relativos à temática da cultura dos negócios. Não por acaso, previa-se a montagem de uma estrutura arquitetônica dotada de jardins, bibliotecas, salas de conferências, salas de leitura, cafés, enfim, espaços que convidassem à reunião dos interessados na promoção do comércio interno e externo de seus produtos. Ao lado das atividades permanentes, os Musées Commerciaux - sempre conectados com instituições comerciais - teriam um calendário próprio para as festas destinadas a reunir as classes produtoras nacionais e os representantes de outros países. A interatividade, as trocas de interesses e saberes e a construção de capital simbólico seriam características cruciais para o bom funcionamento dos museus concebidos por Le Play.

A viabilidade desses museus, sobretudo dos Musées Commerciaux, dependeria da capacidade de seus promotores para utilizarem todos os recursos textuais, orais e visuais disponíveis na época. Ao lado das coleções "vivas", isto é, feitas a partir de produtos in natura, os artefatos visuais teriam a função de "vulgarizar as noções gerais 
de comércio e etnografia"22; simultaneamente, as conferências, sempre a cargo de integrantes do mundo dos negócios e da ciência, dariam legitimidade à publicidade que antecede e facilita as transações comerciais. Daí a previsão da montagem e distribuição, em escala de mercado, de catálogos anuais dos produtos nacionais, folhetos, vistas das principais cidades dos países produtores e compradores, de seus portos, hábitos de vida e consumo. As informações extraídas dos objetos visuais seriam, pois, completadas com aquelas presentes nos mapas, nas estatísticas, coleções de jornais, revistas e nos objetos de arte característicos das regiões e/ou países. Na concepção de Le Play, as coleções in natura atribuiriam dignidade à publicidade comercial; as demais "resolveriam o problema da ignorância sobre o outro, do isolamento entre as classes produtoras, os intelectuais e artistas, razão de ser de negócios malogrados e de incompreensões entre os homens" 23 .

Se não temos notícias da criação dos Musées Generaux, o mesmo não pode ser dito dos Musées Commerciaux ou Musées D'échantions ${ }^{24}$. Aqui e ali persistem fragmentos de seu funcionamento em diversas cidades européias e americanas entre os anos de 1882 e 1908. Estruturados, em geral, a partir da parceria entre poder público e associações comerciais, os museus comerciais deram grande suporte ao comércio que a Europa mantinha com suas colônias e com as jovens nações iberoamericanas. Nossas evidências indicam que tanto o Brasil quanto o México adotaram essa modalidade de publicidade comercial que se tornou rotina nas grandes cidades, sobretudo portuárias, européias a partir das duas últimas décadas do século XIX.

Em 1882, foi criado o Musée Commercial de Bruxelles; dois anos depois o Ministério de Assuntos Estrangeiros da Bélgica inaugurou o Musée Commercial, Industriel et Etnographique de Liège. Em 1884 ele teve 13.587 visitantes, número que subiu para $23.203 \mathrm{em} 1889^{25}$. Mais tarde este museu abriu um escritório na província de Brabant, onde se criou uma seção especializada em coleções de frutas e legumes dissecados. Ainda no território belga, tem-se notícia do Musée de Charleroi, cuja singularidade era a existência de um setor especializado em estudos comerciais. O sucesso dos museus comerciais parece ter sido tal que, em 1900, um dos membros da Societé Geographique Commerciale de Bourdeaux fez um levantamento dos principais museus comerciais existentes na Europa e nos Estados Unidos. Os dados levantados por Albert Mengeot indicam que o Museu Comercial de Filadélfia, aberto em 1894, era o maior e o mais importante do gênero. Além de expor coleções de produtos do mundo inteiro, suas dependências continham salas de conferência, projeção de filmes, leitura e 
uma biblioteca dotada de uma coleção de 1.420 periódicos estrangeiros e nacionais. Em um anexo funcionava um laboratório de experiência e de tecnologia. O museu também publicava um boletim mensal sobre o movimento do comércio internacional nos EUA, o qual continha encartes publicitários de todo o mundo. Coleções de mapas, estatísticas comentadas e fotografias se encarregavam de dar visibilidade às sociedades ali representadas $^{26}$. Experiências inspiradas na proposta de Le Play também estiveram presentes nas cidades de Budapeste, Stuttgart, Dresden, Amsterdan, Leyden e Haarlem $^{27}$. Em 1884, foi criado Museo Commerciale di Turim e, em julho de 1886, a Camara di Commercio di Milano inaugurou o Museo Commerciale di Milano ${ }^{28}$.

Em 2005, os atuais membros da Câmara de Comércio do Trieste decidiram celebrar a memória do Museo Commerciale di Trieste, criado em 1906, ou seja, no mesmo ano da fundação do Museu Commercial do Rio de Janeiro. Inaugurado, agora como um "lugar de memória", para usarmos uma expressão cara a Pierre Nora, o Museo Commerciale de Trieste ${ }^{29}$ reúne objetos pertencentes à história de seu comércio exterior, o qual inclui o Brasil.

De acordo com a documentação produzida pelo Ministério da Indústria, Viação e Obras Públicas do Brasil, entre os anos de 1907/08, foram intensas as relações entre o Museo Commerciale de Trieste e o do Rio de Janeiro. Apenas para exemplificar, lembramos aqui o interesse dos comerciantes da região do Trieste em usar "nossas fibras têxteis" em substituição às fibras de cânhamo e linho, provenientes da Bohemia, Moravia e Áustria Inferior ${ }^{30}$. O alto custo da mão-de-obra nesses países estimulou os fabricantes de tecido da região do Trieste a aventar a possibilidade de adquirir nossas fibras. Simultaneamente, o Museu Commercial do Rio de Janeiro apostou na ampliação do mercado que garantia a manutenção do pacto oligárquico. Para tanto, foram produzidas e divulgadas diversas coleções de tipos de café brasileiro. O mate e as madeiras nacionais, estas muito bem-aceitas no mercado europeu, também contaram com a atenção dos responsáveis de nosso Museu Commercial.

A vida útil do Museu parece ter ocorrido entre os anos de 1907 e $1908^{31}$. Internamente, seus dirigentes montaram uma exposição permanente de produtos de Minas Gerais e da Bahia e ainda se encarregaram de reunir e exibir coleções in natura de produtos de diferentes estados da União. Esse programa, destinado a incentivar os estados a participarem da Exposição Nacional de 1908, também incluía um ciclo de conferências sobre a vida e a produção das regiões do país, realizado entre março e novembro de 1907. Segundo palavras do relator do Ministério de Indústrias, Viação e 
Obras Públicas, "de todas as conferências tem o Museu feito imprimir folhetos para a distribuição gratuita nos Estados, servindo egualmente como fontes de informação para a Commissão de Propaganda no Estrangeiro" ${ }^{\text {32. }}$.

Um mostruário contendo 2.066 amostras de diferentes produtos nacionais foi montado pela "Commissão de Propaganda" do Museu, que estreitou suas relações com

as Câmaras de Commercio de Viena e Vigo, o Office National de Commerce de Paris, Museu Commercial de Marselha, de Bruxellas, Antuérpia, o Deutscher Kolonial Museu, de Berlim, o Export Musterlagar, de Stuttgart, Museu Commercial de Frankfort S/M, de Hamburgo, o Weiner Handels Akademie, Museu Commercial de Budapeste, o Museu Commercial de Barcelona, o Museu Commercial del Fomento del Trabajo de Barcelona, o Museu Commercial de Milão e o Museu Commercial de Philadelphia ${ }^{33}$.

Para efetivar os contatos no exterior, o Museu contou com o Serviço de Propaganda e Expansão do Brazil no Estrangeiro, que, como já assinalado, funcionava no Boulevard d'Italiens, em Paris, desde fins de 1907. Em suas dependências foi instalado o Museu Commercial do Brasil no Estrangeiro, uma espécie de agência de propaganda do Brasil sonhado pelas elites urbanas. Essa sala de exposição recebeu a visita de cerca de 2.000 pessoas, sobretudo de comerciantes, industriais, engenheiros e homens de letras no decorrer de $1908^{34}$. Além de intermediar a remessa de coleções para outros museus, o Serviço de Propaganda também se encarregava de distribuir boletins do Museu Commercial do Rio de Janeiro, relatórios produzidos pelo Centro Industrial do Brazil, os quais eram "editados em francêz, inglêz, allemão e italiano". Este material, organizado em 12 livretos, continha informações sobre

obras públicas (estradas, portos, etc.), correios, telegraphos, saúde publica, commercio interior, exterior e navegação, finanças, producção agrícola e pastoril, minas e minerais, propaganda e expansão economica, leis e regulamentos, relatórios e estatisticas, vários assumptos. ${ }^{35}$

Visando ampliar o raio de repercussão dos temas tratados nas publicações, o corpo diplomático brasileiro usava as salas de conferências dos museus comerciais europeus. Quando proferidas por estrangeiros, as palestras eram feitas por diplomatas, membros das Sociedades Geográficas européias e de ordens religiosas. Em algumas ocasiões, viajantes, homens ou mulheres, que, tendo conhecido o Brasil, também se dispuseram a dar seus depoimentos sobre o país. Este foi, por exemplo, o caso das palestras realizadas em Paris, no teatro Femina. Une promenade à Rio de Janeiro foi o título da palestra feita por Madame de Saint-Genés em 21 de junho de 1908; a Baronesa de Wilson se encarregou de falar sobre Le Brésil, em 12 de dezembro do mesmo ano. 
Sintonizados com a cultura visual disponível no período, os palestrantes quase sempre ilustravam suas falas com "projecções luminosas".

Posteriormente, o próprio Serviço de Propaganda e Expansão Econômica do Brazil no Estrangeiro tratava de publicá-las em brochura"36. Não raro, extratos dessas palestras davam origem a artigos nos jornais locais. As revistas e boletins de Sociedades Geográficas de diferentes países europeus funcionavam como um canal de difusão de boa parte dessas palestras. Em 1908, a Société Geographique de Paris publicou a conferência Une Mission commerciale au Brésil, proferida por Charles Wiener, que, segundo o relator brasileiro, foi um dos eventos mais concorridos do Museu Commercial do Brasil no Estrangeiro. Temos também notícia da reprodução de palestras feitas na Bélgica. Uma sobre Minas Gerais e outra sobre o "Embellezamento do Rio de Janeiro". Há evidências de que os conferencistas também discorreram sobre a borracha na região amazônica, o café, os portos brasileiros, a imigração estrangeira no país, as riquezas minerais, etc. Sua reprodução, parcial ou integral, tinha efeito multiplicador. Além dos casos mencionados, destacamos a palestra realizada em 8 de dezembro de 1908, por um dos membros da "Sociedade de Geographia de Paris", o brasileiro Dr. Everardo Backeuser, intitulada: O Brazil, sua organisação, seu desenvolvimento, seu futuro. Acompanhada de "projecções luminosas", ela foi posteriormente editada na íntegra em La Revue, uma publicação da casa Hachette ${ }^{37}$. Além da França e da Bélgica, cidades alemãs, suíças, inglesas, italianas e espanholas funcionaram como palco para a difusão do material de propaganda brasileiro, onde o Brasil era apresentado como uma sociedade consumidora das inovações tecnológicas e aberta à absorção de mão-de-obra estrangeira.

Animado com as repercussões das conferências, o Serviço de Propaganda no Estrangeiro diversificou suas formas de publicidade. Investiu pesado na edição de livros, mapas, cartões-postais, mata-borrões e textos avulsos sobre as riquezas, os portos e meios de comunicação nacionais. Agindo como um braço do governo republicano, ele promovia a versão moderna do Brasil para ler, ver e ouvir no exterior, ou seja, “... divulgava o progresso e a civilisação do Brazil em todos os ramos da actividade humana" 38 . Os dados que se seguem oferecem-nos uma idéia da dimensão do investimento feito pelo referido órgão. Entre 1907 e 1908, ele distribuiu um total de 139.127 livros e opúsculos; 241.847 mapas diversos e mandou editar 1.814 .337 cartõespostais e pequenos reclames sobre os produtos brasileiros, assim organizados: 
29.000 exemplares em francez, inglez, allemão, italiano, russo e polaco das Bases regulamentares para o serviço do povoamento do solo; 16.000 exemplares em francez, inglez, allemão e italiano da Carta geographica do Brazil; 50.000, nos mesmos idiomas da Carta do Brazil com indicação das vias férreas e de navegação; 120.000, nos mesmos idiomas da Carta do Brazil com indicações das principaes producções de cada Estado: ... ; 1.605 .000 cartões postaes com vistas da capital federal e dos Estados; 100.000 cartões colloridos de propaganda do café: e 300.000 papeis matta-borrão com reclames sobre o café brasileiro ...; além dessas publicações, muitos milhares de exemplares de outras obras taes como: Le Brésil et ses limites actuelles, do Dr. Oliveira Lima; Naturalizations des étrangers au Brésil; O Brazil: suas riquezas naturaes e suas industrias, editado pelo Centro Industrial do Brazil; El Brazil, de Bernades, Amanak Moderno, de Castro Moura, etc. ${ }^{39}$

Esta e outras citações mostram-nos que tanto o Museu Commercial do Rio de Janeiro quanto o Serviço de Propaganda no Estrangeiro não mediram esforços desmontar a representação do Brasil pitoresco tão difundida no imaginário europeu. Tomando como base os estudos sobre a "era de ouro" dos cartões-postais (datada entre 1900-1925), percebemos que a produção brasileira não ficou muito aquém da Alemanha que, ao longo desses 25 anos de pujança econômica, produziu 88 milhões de cartõespostais, ou seja, uma média de 3,5 milhões anuais, ou mesmo da Bélgica e da França, cujas produções foram de 12 e 8 milhões, respectivamente, no mesmo período ${ }^{40}$. Distribuída em universidades, bibliotecas, escolas médias, consulados, redações de jornais, sociedades científicas e outros locais com potencial multiplicador, essa nova modalidade de mercadoria visava projetar no exterior a versão do Brasil afinado com os signos da modernidade industrial. Transcendendo as fronteiras européias, ela chegou ao Marrocos, à Tunísia, à Argélia, ao Japão e à China ${ }^{41}$.

No Brasil, a imprensa se encarregava de noticiar as repercussões sobre "a missão" de propaganda na Europa. No pavilhão brasileiro da Exposição Universal de Bruxelas de 1908, o Serviço de Propaganda no exterior distribuía

chícaras de café e mate, preparados à brasileira", juntamente com "brochuras, cartas gheographicas e outros elementos de propaganda que vae dando bons resultados nos centros intellectuaes e commerciaes da Europa, ainda ignorante da verdadeira situação e recursos de nosso Brazil. ${ }^{42}$

Ainda que a análise do comércio internacional brasileiro escape aos nossos objetivos, é importante salientar que as notícias sobre as propagandas brasileiras no exterior sempre se faziam acompanhar de informações sobre a efetivação de negócios entre o Brasil e as praças comerciais européias.

Cabe destacar, no entanto, que os rituais de sua difusão também comportaram tensões. Em outras palavras, os discursos que emolduravam a positividade da promessa brasileira não evitaram a circulação dos problemas que a arranhavam. Até mesmo um 
relato oficial, destinado a fragilizar as críticas à política de imigração estrangeira no Brasil, deixou vir à tona as vozes contrárias à hegemonia do discurso das elites republicanas. Ao tentar mostrar que versão do Brasil moderno e cosmopolita contava com muitos aliados, o relator do Ministério da Indústria, Viação e Obras Públicas acabou dando voz a seus adversários. Segundo ele, no dia 2 de dezembro de 1908, o salão da Sudamerikanische Gesellschaff, em Berlim, abrira suas portas para a palestra de um renomado membro da Sociedade Alemã de Geografia que se propôs a falar sobre O programa da política econômica do Brazil. Terminada a exposição, "o professor colonial Fabariun, que propaga a colonisação para as colônias da África tomou a palavra e atacou o Brasil”. Imediatamente, “o auditório indignado contra violentos ataques, impediu, pelos seus protestos, que o orador continuasse" ${ }^{\natural 3}$. Sem entrar no mérito dos argumentos do professor colonial, os quais desconhecemos, não há como negar: o episódio narrado nos remete à fuga de imigrantes das fazendas paulistas, que, um ano antes, motivara a suspensão, temporária, da imigração italiana e alemã para o território brasileiro.

Enquanto se difundiam com afinco as imagens do Brasil moderno no circuito europeu, africano e asiático, internamente a média de óbitos provocados pela febre amarela e a epidemia de varíola parecia não se alterar. Entre 27 de julho e 2 de agosto de 1908 - portanto, às vésperas da inauguração da Exposição Nacional que celebraria o primeiro centenário da chegada da Corte Portuguesa ao Brasil - a imprensa noticiou o registro de 231 mortes apenas na Capital Federal ${ }^{44}$. Segundo o jornal oficial do estado de Minas Gerais, "de janeiro até 19 do corrente, a horrível enfermidade na capital matou 2.959 pessoas; a tuberculose fez 76 vítimas na semana e, durante o anno, 1791 pessoas" $"$.

Diante desse quadro, as autoridades republicanas se indagavam: viriam ao Rio as delegações internacionais esperadas para a Exposição Nacional? Como homens da diplomacia e do mercado, seus organizadores tinham consciência de que, além das mercadorias, as epidemias também circulavam livremente no mundo globalizado. Embora estivessem presentes nos quatro cantos do mundo, sabia-se perfeitamente que o público europeu nutria grande receio por seus desdobramentos nas sociedades ditas exóticas.

Se não fosse um sucesso no exterior, a Exposição Nacional deveria, pelo menos, mobilizar o público interno. Este é o sentimento que depreendemos dos discursos sobre a importância do evento que se organizava. $\mathrm{O}$ volume de matérias na imprensa carioca e 
de outros estados do país é um forte indicio de que a classe política, os empresários e a imprensa do país deram grande apoio à realização do "certamen" nacional destinado a "solemnizar o primeiro centenário da abertura dos portos do Brasil ao commercio internacional" ${ }^{46}$. Ao Ministério de Indústria, Viação e Obras Públicas coube redigir as bases para sua organização, sancionadas pelo Decreto n. 6.545 em 4 julho de $1907^{47}$. Em seu artigo $8^{\circ}$, Parágrafo Único, ficara definido: os expositores deveriam, "sempre que possível, enviar photografias de fábricas, usinas, campos de cultura, etc.”, para figurarem ao lado das exposições in natura dos produtos nacionais.

Ainda que um estudo sistemático da Exposição Nacional de 1908 escape aos propósitos deste artigo, cabe destacar: a menção ao uso de imagens na organização dos pavilhões era mais que uma norma burocrática. Sinalizava o reconhecimento de uma prática já assentada na sociedade. Não por acaso, uma parcela significativa do "balanço da riqueza e do desenvolvimento do Brasil depois da emancipação econômica que nos trouxe a abertura dos portos brasileiros, ainda sob o domínio da metrópole

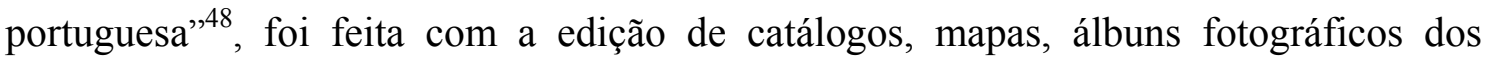
estados, bilhetes postais, selos, medalhas e diplomas.

Materializado em suportes variados, esse conjunto visual manteve o compromisso de destacar e divulgar as imagens do Brasil moderno e cosmopolita no interior de suas próprias fronteiras. Programada para ser inaugurada em agosto de 1908, ela foi efetivamente aberta em 12 de outubro._A partir do mês de setembro, os gravadores, tipógrafos e fototipistas dos jornais e das revistas cariocas encheram os olhos do público da Capital Federal e dos estados com as reproduções fotográficas de Marc Ferrez, Augusto Malta, das firmas dos fotógrafos Luis Musso e J. Buscagli, entre outros. Em todas elas, os profissionais da "imagem mecânica" tratavam de desmontar a memória visual do Brasil pitoresco. A Avenida Central, a Praia Grande, o morro do Corcovado, o Pão de Açúcar e a própria Praia Vermelha onde fora instalada a Exposição Nacional tornaram-se o foco de suas lentes.

Seu portal de entrada, inspirado na última Exposição Universal de Paris, inseria os visitantes nas ruas calçadas com macadame e dotadas de toda a infra-estrutura higiênica. Iluminadas com "15.000 lâmpadas, sendo 8.020 coloridas" "49, suas ruas foram nomeadas com datas e nomes ligados à memória da história nacional. Nelas, abrigavamse os pavilhões em art nouveau, os prédios reservados para o centro médico, corpo de bombeiros, os cafés, restaurantes, teatros, o cinematógrafo, os correios e telégrafos, os espaços para conferências, além dos parques de diversões, dos bondes e jardins, que, 
voltados para as águas da Praia Vermelha, conformavam um complexo urbano ideal. Quer dizer, funcionava como se fosse uma cidade dentro da Capital Federal.

Vitrine da produção nacional, o protótipo de cidade, que era o espaço da Exposição Nacional de 1908, conectava-se ao mercado internacional ao mesmo tempo em que era visto como a oportunidade para dinamizar e diversificar o mercado interno.

Mesmo elegendo o urbano como locus privilegiado de sua modernidade, seus idealizadores não puderam negar sua sustentação rural. Exposta in natura ou em fotografias, a enorme variedade de mercadorias torna presente um passado, hoje em extinção, ao mesmo tempo em que nos coloca diante do aprimoramento e da continuidade de nossos tempos históricos. Esta é a sensação que temos quando os olhos percorrem a relação de produtos expostos.

\footnotetext{
Chapéus de palha, gorros e bonés de lona, espartilhos, esporas, estribos, alpercatas de lona, sapatilhas de couro... ... borracha, acapú, angelin, araribá, cedro, cerejeira, jacarandá, jequitibá, páu brasil, pau rosa, pau setim, café em grão de varios typos, feijão, farinhas diversas, cervejas, vinhos, algodão, conserva de fructas, produtos pharmaceuticos, móveis, chocolate, pano crú, pano alvejado, seda animal, artefatos de ferro, schisto betuminoso, cimento... ${ }^{50}$,
}

Enquanto o público pagante se deliciava com as promessas de progresso na cidade ideal, no Museu Commercial do Rio de Janeiro, no coração da Avenida Central, tinha lugar uma série de conferências e exposições fotográficas de outros estados brasileiros. As imagens de Soucassaux, por exemplo - fotógrafo radicado na capital mineira desde o início dos trabalhos de sua construção, em 1894 -, celebravam a modernidade de Belo Horizonte, uma capital projetada e construída segundo os parâmetros haussmanianos ${ }^{51}$. As imagens de seus parques, casas comerciais, prédios públicos, provavelmente extraídas do Álbum de Belo Horizonte de 1906, de sua autoria, não permitiam ver o quanto a capital mineira tinha um cotidiano pachorrento e, portanto, distinto da dinâmica de uma metrópole, como ela era nomeada por suas autoridades.

Em meio às atividades do Museu Commercial, "lentes da Academia de Commercio do Rio de Janeiro" discorriam sobre a "geographia commercial" do país. Suas palestras, "illustradas com grande número de projecções luminosas de mappas, vistas e quadros estatísticos" ${ }^{\natural 2}$, seguiam os mesmos padrões das conferências sobre o Brasil feitas no circuito dos museus comerciais europeus. 
Retomando a questão da circulação da propaganda do Brasil moderno no exterior, pode-se dizer que, muito provavelmente, as imagens utilizadas no Museu eram reproduções das mesmas matrizes utilizadas pelo Serviço de Propaganda no exterior. Ainda que não tenhamos dados suficientes para avaliarmos a natureza da recepção externa desse esforço de desmonte do Brasil pitoresco, arriscamos a dizer que os europeus tenderam a mesclar as duas representações do país. Ou seja, ao mesmo tempo em que reproduziam em jornais e revistas os dados e as fotografias relativos ao crescimento e ao potencial econômico do Brasil, eles interpretavam essas fontes de informação com os estereótipos que definiam o olhar pitoresco.

Nossa avaliação assenta-se na leitura de um conjunto de revistas editadas na Bélgica pela ordem dos padres Prèmontré de Parc entre os anos de 1910-1911. Interessados em incluir o Brasil em sua rota de evangelização que, à época, abarcava a Inglaterra, o Congo, a Dinamarca e o Canadá, religiosos da Abadia de Parc-LezLouvain visitaram o Brasil em diferentes ocasiões, chegando inclusive a abrir colégios no interior do Mato Grosso e de Minas Gerais. Suas vindas ao Brasil originaram diversos relatos de viagens. Em Une conferénce sur le Brèsi; Cinq Móis au Brèsil e em Dans le Sertão de Minas Gerais, deparamo-nos com o trabalho de colagem de texto e imagem $^{53}$. Neles, tanto encontramos citações relativas aos estudos realizados por membros da Sociedade de Geografia da Bélgica entre 1907 e 1908 - provavelmente extraídos de conferências ilustradas, promovidas pelo Serviço de Propaganda e Expansão Econômica do Brasil no Estrangeiro ao longo do ano de 1908 -, quanto nos deparamos com avaliações, sobre o Brasil, feitas pelos próprios integrantes da ordem Prèmontré de Parc. À medida que as lemos, percebemos que as reproduções fotográficas da Avenida Central no Rio de Janeiro, da Praia de Botafogo, as vistas da Praça da Liberdade e da Secretaria da Agricultura de Belo Horizonte, não eliminavam a visão estereotipada do Brasil, visto por eles como um país exótico e pitoresco.

Em meio a frases de elogio à hospitalidade brasileira, os viajantes belgas inseriam observações sobre a falta de iniciativa dos nativos e seu espírito resignado. Quando o assunto era a vida da Capital Federal, os olhos estrangeiros pousavam detidamente sobre as cores e a exuberância da natureza, a miscigenação racial, a gritaria das ruas, o alto grau de "indigência" nas ruas, etc. Interessados em romanizar os brasileiros, os missionários justificam os investimentos no país e chamam a atenção 
para o potencial desse "vrai paradis", cujo desenvolvimento aguardava a mão inteligente operosa dos europeus ${ }^{54}$.

A presença das imagens nesses relatos de viagem é um bom termômetro para avaliarmos as práticas de uso e apropriação das fotografias no período. Não podemos deixar de observar que as reproduções eram, quase sempre, recortadas, ou seja, reenquadradas de acordo com o gosto dos autores e do editor. Muitas fotografias, que hoje sabemos serem de Marc Ferrez ou de Augusto Malta, eram editadas sem autoria. A falta de clareza na utilização dos tempos verbais dos referidos relatos levava o leitor a acreditar que muitas das fotografias publicadas tinham sido feitas pelos próprios viajantes. Em diversas passagens dos relatos de viagem, termos como "instantâneos" e "tomadas de vistas" vinham acoplados à referências às câmeras fotográficas que eles usavam durante as viagens. Em alguns casos, o uso de reproduções fotográficas que, como dissemos acima, hoje sabemos ser de autoria de Marc Ferrez, Augusto Malta e de Francisco Soucasseaux, tinham legendas em francês. Deparamo-nos, ainda, com um caso de apropriação deliberada da autoria dessas imagens. Uma das fotografias de uma cachoeira no interior de Minas Gerais traz a assinatura de Jean Malvaux. Pelo que pudemos apurar, este fotógrafo pertenceu à Société Française de Bienfaisance de Bruxelles e era proprietário do Établissements phtografique Jean Malvaux. Nossa hipótese é a de que ele tenha sido contratado pela ordem Prèmontré de Parc para fotografar seus membros na Bélgica, pois todas as fotografias de membros da ordem, feitas na Bélgica trazem sua assinatura. Mais que denunciar tal apropriação, a menção a este fato visa destacar a questão da reprodutibilidade das imagens, sobretudo da fotografia, como um fator da economia de mercado. 


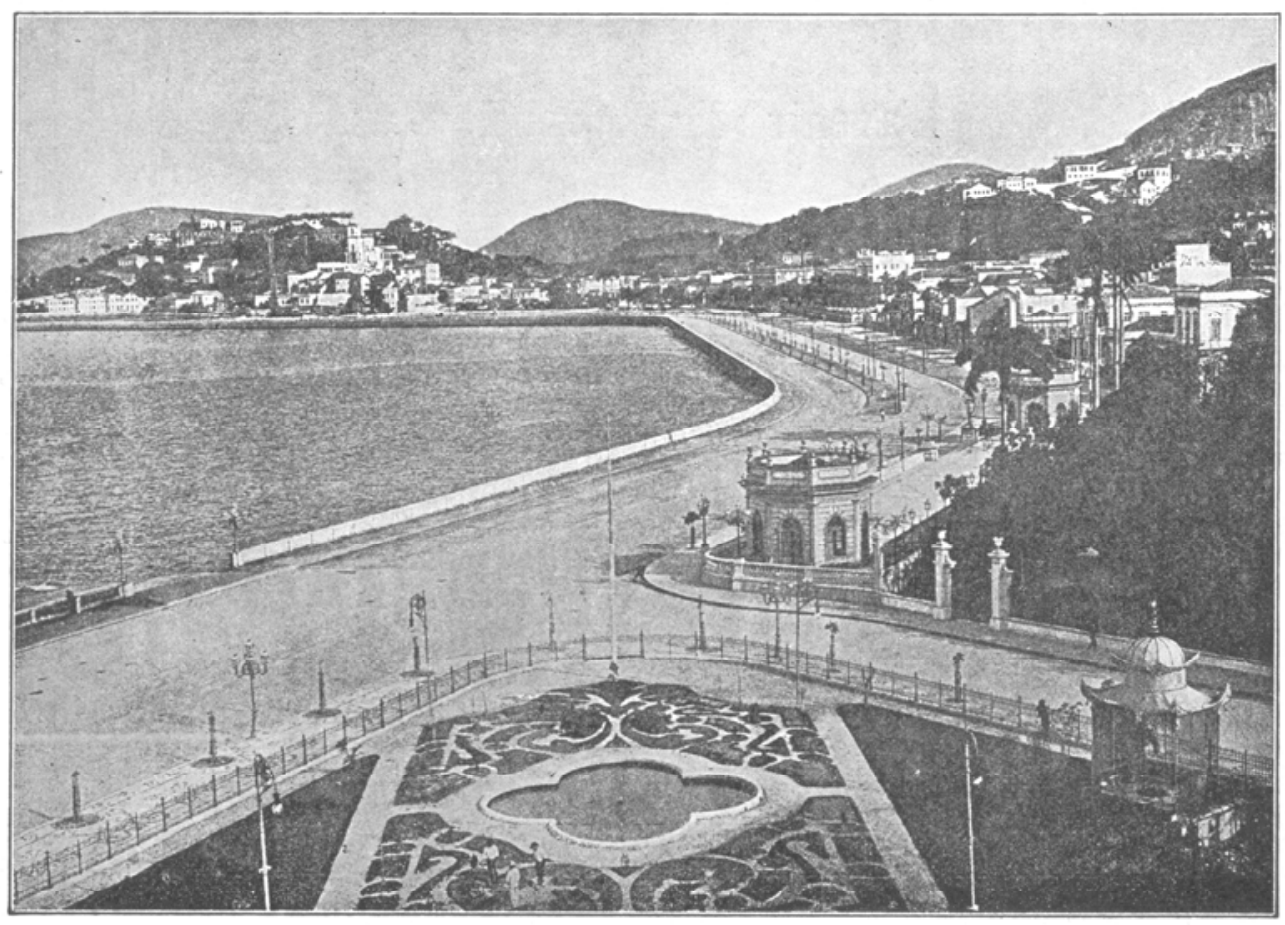

AVENUE BEIRA-MAR A RIO DE JANEIRO.

Figura 01 - Fonte: GASPAR, O P. Marcel M. Une conferénce sur le Brèsil- l'avenir d'un grand pays. Louvain: Imprimerie Meuleimans de Pretes, 1910.p.06

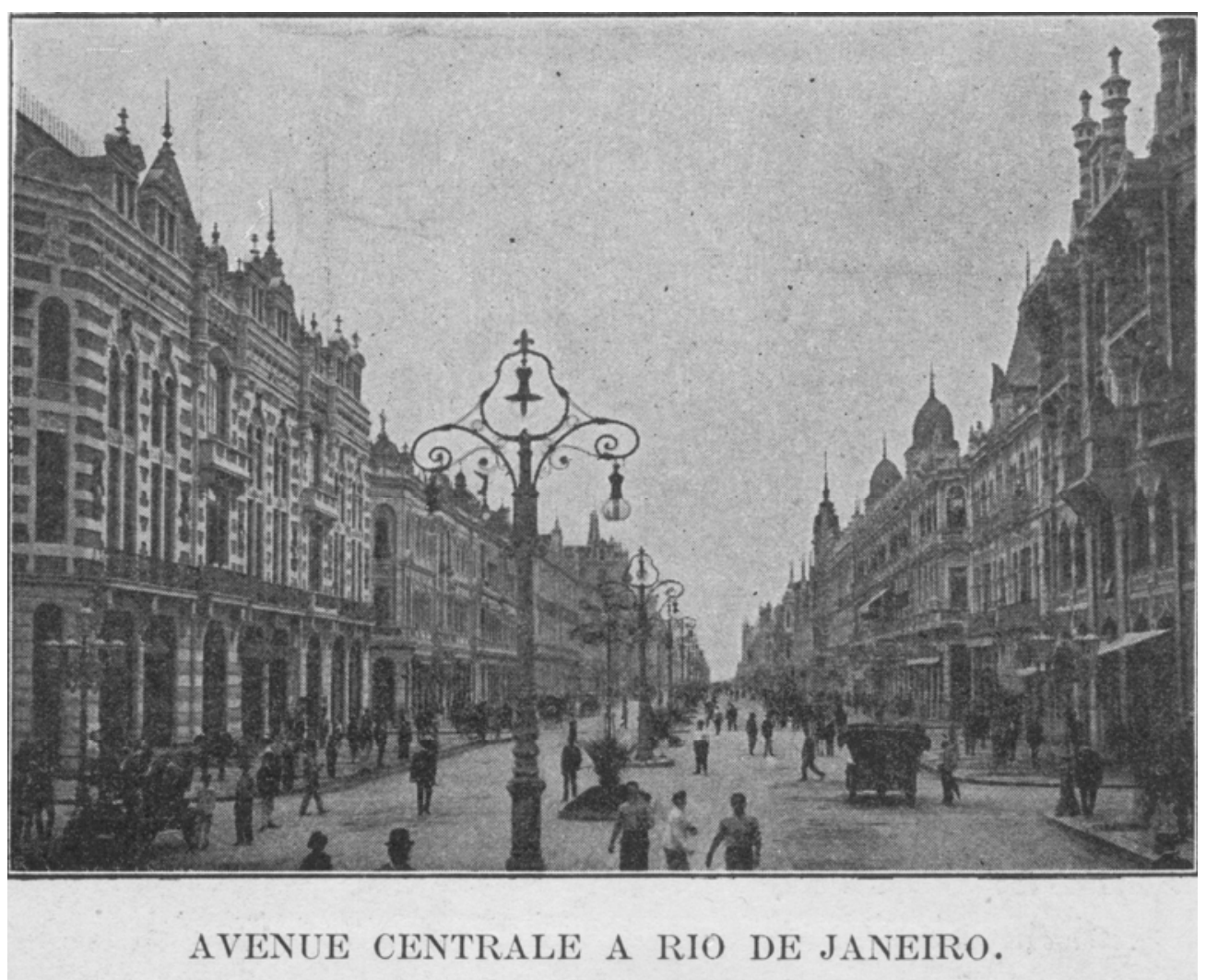

Figura 02 - Fonte: GLÉNISSON, Édouard-Gustave. Cinq Móis au Brèsil - Souvenirs\&Impressions de Voyage. Louvain: Imprimerie Pierre Smberstrers, 1911.p.06 
Tanto a figura 01 quanto a 02 apresentam fragmentos do Rio de Janeiro remodelado pela reforma Pereira Passos. A primeira imagem (fig. 01), tirada de um plano superior aos postes de iluminação da avenida, sugere calma e aconchego. Com a entrada pelo ângulo formado entre a curva do espaço ajardinado e o início da passarela à beira-mar, o fotógrafo convida o observador a deslocar-se numa paisagem feita tanto por fragmentos de natureza indomada quanto domesticada pela ação engenhosa dos "urbanistas" afinados com a estética haussmaniana. Enquanto ela celebra e monumentaliza a paisagem, a segunda fotografia (fig. 02) dá ênfase ao cotidiano do coração da Capital Federal: a Avenida Central. Jogando com a perspectiva, esse recorte de uma das fotografias de Malta coloca o observador entre os ícones da modernidade: avenida larga, extensa e movimentada, dotada de iluminação sustentada por armações de ferro, automóveis e arquitetura padronizada. Como membro da nova confraria internacional, a confraria dos flâneurs, Malta sabia que esta imagem, assim como outras produzidas pela comunidade de fotógrafos comprometidos com os valores modernizantes, era um testemunho que certamente contribuiria para fragilizar a memória do Brasil pitoresco.

O uso em escala de mercado das “imagens mecânicas" tinha, naquele momento, o papel de prova, de evidência. Sua natureza indicial legitimava as teses que tendiam a sobrepor real e representação fotográfica. A série de imagens como as que apresentamos aqui, hoje tão conhecidas dos estudiosos da história da fotografia brasileira, tinha, de fato, a intenção de mostrar que o Rio de Janeiro dos anos novecentos não era mais a cidade dos negros de ganho e das ruas sem esgoto que os viajantes do século XIX tinham narrado com detalhes e em tom pitoresco. Seguramente, as representações fotográficas que compuseram o lote de " 1.605 .000 cartões postaes com vistas da capital federal e dos Estados", anteriormente referido, tinham características semelhantes às duas imagens aqui apresentadas. Se, por um lado, podemos afirmar que elas tiveram papel importante na difusão de um novo imaginário sobre o Brasil dos primeiros anos da era republicana, por outro, não é demais lembrar: nem sempre os receptores externos acompanharam as intenções dos artífices da nova visualidade brasileira. Para os estrangeiros, mais do que para os brasileiros, o Brasil moderno não eliminou de todo o Brasil pitoresco. Aliás, não seria incorreto afirmar que uma porção pitoresca do país sempre foi reafirmada pelas elites republicanas. Entre os ingredientes formadores da 
tradição histórica nacional a que o Brasil moderno pretendia dar continuidade, estavam a tão propalada hospitalidade brasileira, a musicalidade e a espontaneidade do povo.

\section{Considerações Finais}

Algumas questões podem ser depreendidas do conjunto de evidências apresentadas ao longo deste artigo. Com partes da fabricação do imaginário que almejava inserir o Brasil na nova divisão internacional do trabalho, os dados analisados denotam escolhas que iluminam, representam e atribuem sentido a uma fração da sociedade brasileira. Em primeiro lugar, elas sinalizam a orquestração de um verdadeiro comércio entre boca, ouvido e olhos, destinado a criar uma comunidade de sentido dentro e fora das fronteiras nacionais. Indício da sintonia das elites republicanas com a cultura publicitária do período, esse comércio teve endereço certo: visou atingir consumidores, nacionais e internacionais, de distintas classes sociais. Editados em diferentes suportes e línguas, os bens simbólicos tiveram um papel crucial no âmbito do comércio destinado a substituir o Brasil pitoresco por outro mais moderno e funcional aos interesses das classes conservadoras brasileiras. Por isso mesmo, as práticas publicitárias do Brasil sonhado por suas elites dirigentes não dispensaram o uso e, em certos casos, o abuso de adjetivos para qualificar a idéia de progresso e, sobretudo, a promessa de um grande "avenir" relacionada com o país. Com esses atributos, a articulação entre textos, imagens e palavras procurou produzir e vender a imagem de um Brasil cosmopolita, em processo de modernização, aberto ao capital e ao trabalho de quem apostasse numa vida melhor.

Certamente que a produção do Brasil para ler, ver e ouvir no circuito externo e interno não teria cumprido minimamente seu papel de mercadoria se ela não tivesse algum tipo de lastro com a realidade. Ora, se observados os dados sobre os investimentos que abarcavam as melhorias de infra-estrutura dos portos, a construção da malha ferroviária nos estados, a adequação dos correios e telégrafos às normas internacionais, a legislação relativa à remodelação do serviço de estatística, o investimento nas políticas de educação e saúde pública, bem como os melhoramentos urbanos do Rio de Janeiro e de algumas capitais de estado, veremos que, de fato, as elites republicanas se empenharam em adequar o país aos paradigmas da modernidade industrial que norteavam, também na Europa, a criação de um imaginário social centrado no binômio civilização/progresso tecnológico. Tudo isso foi fundamental para 
legitimar e atribuir credibilidade aos discursos e programas publicitários levados adiante pelas autoridades brasileiras.

Sem entrar no mérito das singularidades dos casos europeus, não é demais lembrar, como fazem diversos estudos sobre as práticas e os desdobramentos da modernização industrial na Europa - principalmente aqueles voltados para a análise dos processos de reurbanização de suas capitais -, que mostram o quanto suas medidas modernizadoras também foram seletivas. Concentradas nas áreas portuárias, nos centros das cidades e nos bairros de alto poder aquisitivo, assim como ocorreu em diferentes cidades do Brasil, elas se apoiaram na exploração imobiliária e também excluíram dos cenários higienizados e ajardinados os atores que moviam suas indústrias e seu comércio ambulante. Outro aspecto que também favoreceu a solução dos problemas econômicos, políticos e sociais dos países europeus foi a expulsão de grande parte de seus habitantes pobres que, incentivada pela onda de imigração, deslocou-se para as Américas. Por fim, cabe enfatizar: assim como no Brasil, a circulação da cultura visual, sobretudo da fotografia, muito contribuiu para plantar e difundir comunidades imaginárias de viés modernizante nas sociedades européias ${ }^{55}$. A força desse tipo de percepção do processo histórico foi tal que nem mesmo a primeira Grande Guerra, que pôs fim à belle époque, logrou aniquilá-lo. Fragilizada, essa visão da história, finalista $\mathrm{e}$ evolucionista, e que, sobretudo, fecha os olhos para as individualidades históricas, retomou fôlego, adquiriu novas vestimentas e animou grande parte das políticas econômicas do século XX.

Com isso queremos dizer que a representação moderna do Brasil para ler, ver e ouvir no circuito europeu, e também nacional, não foi uma particularidade das elites brasileiras dos primeiros anos da República. Ao contrário, integrou uma cultura em voga em diferentes partes do mundo. O que o diferencia de outras sociedades é o modo como aqui se teatralizou a "saga da modernidade industrial". Ao lado de práticas sociais e políticas excludentes e autoritárias, a difusão das imagens do progresso ajudou a criar, difundir e padronizar hábitos, comportamentos e percepções sociais que editados e reeditados acabaram por fortalecer a crença de que a transição do Brasil pitoresco, préindustrial, para o Brasil moderno, industrial, dependia quase que exclusivamente de fatores econômicos e tecnológicos. Ao jogarem luz no potencial hidráulico do país, na aquisição de inovações tecnológicas e nas remodelações dos espaços urbanos, nas indústrias, os fotógrafos, contratados ou não pelo poder público, davam vida ao mundo das coisas, mais do que de seus fabricantes. Quando presentes nas fotografias, os 
operários se confundiam com os artefatos; em outras situações os indivíduos entravam nas imagens apenas para que o observador pudesse ter a dimensão da exuberância da natureza. Nas fotografias de inauguração de obras públicas, as lentes fotográficas tendiam a produzir a sensação de celebração. A repetição ad infinitum desse padrão de visualidade certamente contribuiu para fortalecer a tese do efeito cascata dos indicadores materiais do progresso, a qual dizia que as margens do país - sua massa de excluídos - seriam automaticamente contagiadas pelas benesses da tecnologia. O que as elites republicanas parecem não ter percebido é que o gerenciamento dos novos tempos também pressupunha romper com a tradição de uma memória social excludente e autoritária. Por isso, os atores que não puderam, ou não quiseram, representar os papéis sociais nos cenários desenhados pelas elites dirigentes foram considerados empecilhos para a concretização desse "vrai paradis".

BORGES, Maria Eliza Linhares. Representations of Modern Brazil to read, to see and to hear in the circuit of the European Museums Trade, from 1906 to 1908. História, São Paulo, v. 26, n. 2, p. 92-117, 2007.

Abstract: The article focuses the visual culture role in the construction of Brazilian national identity during the first period of the Republican age. It analyzes the publicity practices of Brazilian elites aimed at replacing the image of a picturesque Brazil, widespread within and outside the country since the $\mathrm{XIX}^{\text {th }}$ century, with a new image, more akin to the signs of a modern, cosmopolitan society. It emphasizes the production and circulation of symbolic goods issued by Museu Commercial of Rio de Janeiro and Brazilian Museu Commercial in Paris, in partnership with Brazilian Service of Foreign Propaganda and Economic Expansion, just before the 1908 National Exhibition held to celebrate the centenary of the Portuguese Court's arrival to Brazil.

Keywords: Visual Culture, Circulation of Symbolic Goods, National Identity

Artigo recebido em 09/2007. Aprovado em 10/2007.

\section{NOTAS:}

* Prof $^{\mathrm{a}} \operatorname{Dr}^{\mathrm{a}}$ Dept $^{\mathrm{o}}$ História da Faculdade de Filosofia e Ciências Humanas da UFMG. Belo Horizonte. 30310-500 (MG), Brasil.

1 Sobre o debate teórico-metodológico em torno da idéia de cultura visual, ver a bela análise de: MENEZES, U. T. B. de. Fontes visuais, cultura visual, História visual. Balanço provisório, propostas cautelares. Revista Brasileira de História. São Paulo: Marco Zero, v. 23, n. 45, 2003. p. 11-36.

${ }^{2}$ Usamos os conceitos de logosfera, grafosfera e videosfera conforme definidos por Régis Debray em seu estudo sobre a História do Olhar no Ocidente. Ordenada em idades, tal história se inicia com a logosfera, a qual vai da invenção da escrita ao surgimento da imprensa. Aí, as imagens pertencem à ordem do ídolo; têm magia. Seu significado advém do além. A grafosfera é a segunda idade do olhar; inicia-se com a 
imprensa e estende-se até a invenção da TV. Nela, as imagens têm valor artístico e histórico. Como ícones, inauguram a era das representações. A terceira idade: a videosfera, teve início em 1968 e vigora até os dias atuais. Naquela data, o mundo viveu uma experiência ímpar: assistiu pela primeira vez, via satélite, aos jogos olímpicos ocorridos na Cidade do México. $\mathrm{Na}$ videosfera as imagens são símbolos e pertencem ao reino dos acontecimentos. Para nossos objetivos, importa ressaltar que a periodização proposta por Debray, ainda que esquemática, chama atenção para a dimensão dialética das idades do olhar, bem como para sua vinculação com as culturas que as produzem. Segundo ele, cada idade anuncia fragmentos da seguinte ao mesmo tempo em que re-significa as características da anterior. Sobre essas questões, ver: DEBRAY. R. Vida e morte da imagem: uma história do olhar no Ocidente. Petrópolis: Vozes, 1993.

${ }^{3}$ DEBRAY, R. Acreditar, ver, fazer. SP/Bauru: Edusc, 2003. p. 129-138.

${ }^{4}$ BENJAMIN, W. A obra de arte na era de sua reprodutibilidade técnica. In: Magia e técnica, arte e política - ensaios sobre literatura e história da cultura. São Paulo: Brasiliense, 1985. p. 165-196. (Obras escolhidas, v. 1)

${ }^{5}$ Sobre o mercado em escala mundial de litografias, ver: ZENHA, C. O Brasil de Rugendas nas edições populares ilustradas. Topoi. Rio de Janeiro, n. 5, dez./2002, p. 134-160.

${ }^{6}$ A bibliografia sobre as Exposições Universais é extensa e diferenciada. Sobre o papel da fotografia nesses eventos, ver especialmente: TURAZZI, M. I. Poses e trejeitos: a fotografia e as exposições na era do espetáculo (1839-1889). Rio de Janeiro: Rocco/Funarte, 1995. Ver também: HARDMAN, F. F. Exposições universais: breve itinerário do exibicionismo burguês. In: Trem fantasma - a modernidade na selva. São Paulo: Companhia das Letras, 1988; PESAVENTO, S. J. Exposições Universais - espetáculos da modernidade do século XIX. São Paulo: Hucitec, 1997.

7 NARANJO, J. (ed.). Fotografia, antropología y colonialismo (1845-2006). Barcelona: Gustavo Gili, 2006.

${ }^{8}$ BOLLE, W. Fisiognomia da metrópole moderna. São Paulo: Edusp/Fapesp, 2000. p. 396 e segs.

${ }^{9}$ TURAZZI, M. I. Paisagem construída - fotografia e memória dos 'melhoramentos urbanos' na cidade do Rio de Janeiro. Varia História. Belo Horizonte: Programa de Pós-Graduação em História/UFMG. Jan./jun. 2006, v. 22, n. 35, p. 66. Em outro estudo, a pesquisadora em questão chama atenção para a participação da fotografia nas seguidas Exposições Nacionais que aconteceram no país ainda no período imperial, ou seja, entre 1861 e 1881. Ainda que boa parte dos fotógrafos premiados tenha mostrado fragmentos do Brasil moderno, ainda nesse período as representações do Brasil pitoresco conviviam quase que pacificamente com as do Brasil que almejava ser reconhecido como um país cosmopolita e em processo de modernização. Sobre o lugar da fotografia nas Exposições Nacionais do Império, ver: TURAZZI, M. I. Paisagem construída - fotografia e memória dos 'melhoramentos urbanos' na cidade do Rio de Janeiro. Varia História. Belo Horizonte: Programa de Pós-Graduação em História/UFMG. Jan./jun. 2006, v. 22, n. 35, p. 68 e segs. Em geral, essas exposições funcionaram como "ensaios" para a participação brasileira nas Exposições Universais. Lembre-se de que o Brasil esteve presentes nas Exposições de 1862 (Londres); 1867 (Paris); 1873 (Viena), 1876 (Filadélfia) e, no século XX, esteve presente nas Exposições Universais de 1904 (São Luis/USA); 1910 (Bruxelas) e 1911 (Turim). Sobre este assunto, ver; ARAUJO, H. R. de. Técnica, trabalho e natureza na sociedade escravista. Revista Brasileira de História. São Paulo: Marco Zero/ANPUH. v. 18, n. 35, 1998. Dentre os muitos estudos sobre a participação da fotografia no período imperial, destacamos: VASQUEZ, P. K. A fotografia no Império. Rio de Janeiro: Zahar, 2002; KOSSOY, B. Origens e expansão da fotografia no Brasil, século XIX. São Paulo: Funart, 1980.

${ }^{10}$ SEGALA, L. Victor Fronde et le projet photographique du Brésil Pittoresque. Colloque International "Voyageurs et images du Brésil". MSH-Paris. 2003. Table: Missions Artistiques et espéditions scientifiques. XIX - début de $\mathrm{XX}^{\mathrm{e}}$ siècle. http://www.chairesergiobuarque.msh-paris.fr/pdfvoyageurs/interv3.pdf (consultado entre maio e junho de 2007).

${ }_{11}$ Sobre essas questões, ver os artigos da Kósmos, Revista Artística, Scientífica e Literária. Rio de Janeiro: Rua da Assembléia, 62. Anno III, IV e V, 1906 a 1908; A revista Fon-Fon e o jornal Correio da Manhã, entre maio e novembro de 1908, também apresentam uma série de matérias nessa mesma direção (Acervo da Biblioteca Nacional do Rio de Janeiro).

${ }^{12}$ A bibliografia disponível sobre esse período bem como a documentação da época mostram que as diferentes orientações políticas e ideológicas das elites republicanas não eliminaram a herança autoritária que norteava as políticas de modernização nas áreas urbanas. No campo, a crise do sistema coronelista não eliminou o banditismo social nem tampouco mudou as relações de mando tipicamente patriarcais. Sobre essas questões, ver: MARTINS, J. de S. Os camponeses e a política no Brasil. Petrópolis: Vozes, 1981; CARVAlHO, J. Murilo de. Os Bestializados: o Rio de Janeiro e a república que não foi. São Paulo: Companhia das Letras, 1987. Sobre as elites republicanas, ver: CARVALHO, J. Murilo de. 
Cidadania na encruzilhada. In: BIGNOTTO, N. (org.). Pensar a República. Belo Horizonte: Ed UFMG, 2000. p. 105-130.

13 RELATORIO anexo: êxodo de immigrantes em São Paulo. 1907. p. IX. In: Center For Research Libraries. Brazilian Government Document Digitization Project. Ministerial Reports, 1821-1960, http://brazil.crl.edu/bsd/bsd/hartness/minopen.html (consultado entre maio e junho de 2007).

${ }^{14}$ Ibidem, p. IX.

${ }^{15}$ Ibidem, p. IX.

${ }^{16}$ Center For Research Libraries. Brazilian Government Document Digitization Project. Ministerial Reports, 1821-1960. Ano 1908. p. XIV http://brazil.crl.edu/bsd/bsd/hartness/minopen.html

${ }^{17}$ Ibidem, p. XIV.

${ }^{18}$ Ibidem,1908. p. XIV e 1909. p. 76.

${ }^{19}$ Ibidem.

${ }^{20}$ LE PLAY, F. Remplacement des Expositions Temporaires par des Expositions Permanentes, dite Musées Genéraux ou Commerciaux; Avenir des Expositions: Organizations des Musées Commerciaux. In: Rapport sur L'Exposition Universelle de 1867, a Paris. Paris: Imprimerie Imperiale. Capítulos X ao XIV, $\quad$ respectivamente, $1869, \quad$ p. $\quad 279-328$. http://cnum.cnam.fr/CGI/fpage.cgi?8XAE148/305/100/653/652/653 (consultado entre maio e junho de 2007). Ver também: LARA FILHO, D. de. Museu: de espelho do mundo a espaço relacional. São Paulo, 2006. Dissertação (Mestrado ECA-USP).

${ }^{21}$ LE PLAY, F. Remplacement des Expositions Temporaires par des Expositions Permanentes, dites Musées Genéraux ou Commerciaux; Avenir des Expositions: Organizations des Musées Commerciaux. In: Rapport sur L'Exposition Universelle de 1867, à Paris. Paris: Imprimerie Imperiale. Capítulos $\mathrm{X}$ ao

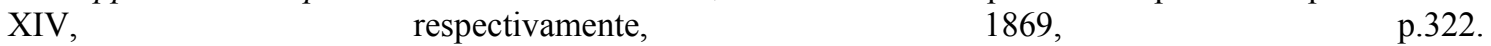
http://cnum.cnam.fr/CGI/fpage.cgi?8XAE148/305/100/653/652/653Ibidem (consultado entre maio e junho de 2007).

${ }_{22}$ Ibidem, p. 322.

${ }^{23}$ Ibidem, p. 322.

${ }^{24}$ DELMAS, P. e MENGEOT, A. Ce que doit être um Musée d; échantions. p. 353-360; MENGEOT, A. Musées Commerciaux et Coloniaux à l'étranger. p. 78-84. Société De Geographie Commerciale de Bourdeaux. jan./dez. 1900. http:/gallica.bnf.fr/ark:/12148/bpt6k104700f/f72.table (consultado entre maio e junho de 2007).

${ }^{25}$ Ibidem.

${ }^{26} \mathrm{http}$ ://encyclopedia.jrank.org/fr/PER PIG/PHILADELPHIE.html, p. 79.

${ }^{27}$ MENGEOT, A. Musées Commerciaux et Coloniaux à l'étranger. p. 78 e 84. Société De Geographie Commerciale de Bourdeaux. jan./dez. 1900. p. 78-84; MENGEOT, A. Musées Commerciaux et Coloniaux Français. p. 249-253. http://gallica.bnf.fr/ark:/12148/bpt6k104700f/f72.table

${ }^{28} \mathrm{http}: / /$ pereco.lombardiastorica.it/index.php?page $=$ testo\&id $=188 \&$ ric $=1$

29 http://www.ts.camcom.it/tseconrivista05.htm

30 .Center For Research Libraries. Brazilian Government Document Digitization Project. Ministerial Reports, 1821-1960; 1907-1909. p. 5-15, http://brazil.crl.edu/bsd/bsd/hartness/minopen.html

31 Até o momento, não foram encontradas evidências de suas atividades após 1908.

32 Center For Research Libraries. Brazilian Government Document Digitization Project. Ministerial Reports, 1821-1960; 1908. p. 12-13 http://brazil.crl.edu/bsd/bsd/hartness/minopen.html.

${ }^{33}$ Ibidem,1908. p. 12.

${ }^{34}$ Ibidem, 1909-1. p. 177.

${ }^{35}$ Ibidem, p. 178-179.

${ }^{36}$ Ibidem. Conferencias. p. 181.

${ }^{37}$ Ibidem, p. 181.

${ }^{38}$ Ibidem, p. 183.

${ }^{39}$ Ibidem. p. 181-184

${ }^{40}$ KOSSOY, Boris. Realidades e ficções na trama fotográfica. 2. ed. São Paulo: Ateliê Editorial, 2000. p. 64. Sobre o lugar dos cartões-postais na cultura visual da época, ver: BORGES, Maria Eliza L. História \& Fotografia. 2. ed. Belo Horizonte: Autêntica, 2005. p. 58-62.

${ }^{41}$ Ibidem, p. 184. Vale a pena destacar que o hábito de usar as imagens como propaganda é anterior à era dos cartões-postais. Não podemos nos esquecer de que, na década de 1880, o fotógrafo Marc Ferrez já havia feito uma série de panoramas do Rio de Janeiro, e outra sobre as fazendas de café do Vale do Paraíba. As legendas em francês, de muitas delas, são indício de se destinarem ao público estrangeiro. Não obstante, é importante lembrar que uma parcela das fotografias de Ferrez mostra o Brasil pitoresco e 
escravocrata. Sobre essas questões, ver: O BRASIL de Marc Ferrez, 1843-1923, Crítica e Interpretação. São Paulo: Instituto Moreira Salles, 2005.

${ }^{42}$ A PROPAGANDA do Brasil na Europa. Noticiário. Minas Geraes. Bello Horizonte, n. 246. Sexta feira, 16 de outubro de 1908. p. 2. Acervo da Hemeroteca do Estado de Minas Gerais.

${ }^{43}$ Center For Research Libraries. Braziliam Government Document Digitization Project. Ministerial Reports, 1821-1960; 1908. p. 181. http://brazil.crl.edu/bsd/bsd/hartness/minopen.html

${ }^{44}$ Correio da Manhã . Rio de Janeiro. 7 de agosto de 1908. p. 1. Acervo da Biblioteca Nacional do Rio de Janeiro.

${ }^{45}$ NOTICIARIO. Minas Gerais. Bello Horizonte. 21 de agosto de 1908. n. 198. p. 6. Hemeroteca do Estado de Minas Gerais.

${ }^{46}$ Center For Research Libraries. Brazilian Government Document Digitization Project. Ministerial Reports, 1821-1960. Exposição Nacional. 1908. p. 25, http://brazil.crl.edu/bsd/bsd/hartness/minopen.html ${ }^{47}$ Ibidem, BASES para a organização de uma Exposição Nacional, em 1908. p. 27.

${ }^{48}$ Ibidem, p. 30.

${ }^{49}$ EXPOSIÇÃO Nacional. Correio da Manhã. Rio de Janeiro, 7 de julho de 1908. p. 2. Acervo da Biblioteca Nacional do Rio de Janeiro.

${ }^{50}$ Center For Research Libraries. Brazilian Government Document Digitization Project. Ministerial Reports, 1821-1960. Museu Commercial, 1908. p. 6-8, http://brazil.crl.edu/bsd/bsd/hartness/minopen.html

${ }^{51}$ EXPOSIÇÃO Photographica. Revista da Semana. Rio de Janeiro. Anno VIII. 14 de julho de 1908. p. 13. Acervo da Biblioteca Nacional do Rio de Janeiro.

52 Center For Research Libraries. Brazilian Government Document Digitization Project. Ministerial Reports, 1821-1960. MUSEU Commercial. 1901-1. p. 24. http://brazil.crl.edu/bsd/bsd/hartness/minopen.html

${ }^{53}$ GASPAR, O. P. Marcel M. Une conferénce sur le Brésil- l'avenir d'un grand pays. Louvain: Imprimerie Meuleimans de Pretes, 1910; GASPAR, O. P. Marcel M. Dans le Sertão de Minas Gerais ouvrage illustré de 45 simili-gravures et d'une carte. Louvain: Imprimerie Meuleimans de Pretes, 1910; GLÉNISSON, Édouard-Gustave. Cinq Móis au Brésil - Souvenirs\&Impressions de Voyage. Louvain: Imprimerie Pierre Smberstrers, 1911.

${ }^{54}$ GASPAR, O. P. Marcel M. Une conferénce sur le Brésil- l'avenir d'un grand pays. Louvain: Imprimerie Meuleimans de Pretes, 1910. p. 37.

${ }^{55}$ Sobre essas questões, ver: TAGG, John. La ley sanitaria de Dios: erradicación de viviendas insalubres y fotografía en el Leeds de finales del sigo XIX. In: El peso de la representación. Barcelona: Gustavo Gili, 2005. p. 153-198; BADGER, Ferry (ed.). Eugene Atget. New Cork, Phaidon Press Limited, 2001; ZIMMERMANN, Clemens. L'era delle metropoli. Bologna: Mulino, 2004. 